\title{
STRATEGI COPING SANTRI DALAM MENGHADAPI STANDAR KELULUSAN DI PONDOK PESANTREN
}

\author{
Oleh: \\ Tirtha Segoro \\ Universitas Muhammadiyah Surakarta
}

\begin{abstract}
Abstrak
Penelitian ini bertujuan untuk memahami dan mendeskripsikan persepsi santri terhadap standar kelulusan, bentuk-bentuk strategi coping santri dan faktor-faktor yang mempengaruhi strategi coping santri dalam menghadapi standar kelulusan di pondok pesantren. Karakteristik informan adalah santri PPMI Assalaam dan PPA Al-Muayyad, kelas XII SMA, berusia 16-18 tahun, santri yang memiliki prestasi akademik tinggi dan santri yang memiliki kesulitan dalam menghadapi standar kelulusan. Informan berjumlah enam orang dan metode pengambilan data yang dipakai adalah wawancara.

Hasil penelitian: 1) Persepsi santri terhadap standar kelulusan, yaitu setuju khususnya syarat kelulusan pondok karena membawa pengaruh positif bagi santri dan tidak setuju khususnya syarat kelulusan UN karena membebani dan dirasa banyak ketidakadilan; 2) Strategi coping yang dilakukan santri, yaitu emotion-focused coping yang meliputi izin keluar komplek, berhubungan dengan lawan jenis, membuka online-shop, bercanda dengan teman satu kamar, membaca buku cerita, menghibur diri dengan bernyanyi dan mencuci baju. Namun, strategi coping yang paling efektif bagi santri adalah adalah problem-focused coping, meliputi memilih tempat yang kondusif, menyicil dari tahun sebelumnya, sering membaca dan mengulang-ulang, rutin berkonsultasi dengan pembimbing, mengimbangi belajar (mengikuti bimbingan belajar, memperbanyak latihan soal, bekerja dan belajar bersama dengan teman), meningkatkan ibadah dan konsisten dalam menjalankan aktivitas tersebut; 3) Faktor-faktor yang mempengaruhi strategi coping santri yaitu karakteristik personal, persepsi diri, dukungan keluarga, sekolah dan sosial dalam hal ini adalah teman karena di pondok pesantren teman merupakan dukungan sosial yang paling dekat.

Kesimpulan dari hasil penelitian ini adalah santri melakukan problem-focused coping sebagai cara yang paling efektif dalam menghadapi standar kelulusan. Implikasi yang dapat diberikan yaitu perlu adanya dukungan dari keluarga, sekolah dan teman kepada santri dalam menghadapi standar kelulusan.
\end{abstract}

Kata kunci : strategi coping, santri, standar kelulusan

\section{A. Pendahuluan}

Dewasa ini telah banyak ditemukan corak pondok pesantren sebagai salah satu lembaga pendidikan yang mencoba mengimbangi tuntutan modernisasi dengan beragam pembenahan di 
berbagai bidang, antara lain: bangunan fisik, fasilitas ruang, kurikulum, kreatifitas pengajar dan input santri. Pondok pesantren berusaha mengaplikasikan pendidikan yang berorientasi ilmu syar'i dan ilmu pengetahuan umum yang diharapkan mampu membentuk profil kelulusan yang menjawab tuntutan zaman dan beradaptasi dengan perkembangan masyarakat.

Seperti di salah satu pondok pesantren modern yang menetapkan profil dan kategori kelulusan berdasarkan workshop pendidikan pada tanggal 14 Maret 2010, yaitu profil lulusan dari segi spiritual (memiliki aqidah salimah, mampu menghafal minimal 3 juz (juz 30, 1 dan 2), mampu berpidato dalam tiga bahasa, mampu menjadi imam dan khotib dan mampu mendirikan ibadah wajib dan sunnah), intelektual (memiliki rata-rata nilai murni Ujian Akhir Pondok minimal 6, mampu berkomunikasi dalam bahasa Arab dan Inggris, mampu menulis karya tulis/paper berbahasa asing dan menguasai aplikasi komputer dan internet) dan moral (memiliki suluk jayyid, memiliki jiwa kepemimpinan, memiliki kepedulian terhadap lingkungan dan mampu mengabdikan kepada masyarakat). Selain standar kelulusan yang ditetapkan oleh pondok pesantren modern, santri dihadapkan pula dengan standar kelulusan yang ditetapkan oleh negara melalui Ujian Nasional. Tujuan dalam penelitian ini adalah untuk memahami dan mendeskripsikan persepsi santri terhadap standar kelulusan yang ditetapkan oleh pondok pesantren, bentuk-bentuk strategi coping santri dalam menghadapi standar kelulusan di pondok pesantren dan faktor-faktor yang mempengaruhi strategi coping santri dalam menghadapi standar kelulusan di pondok pesantren.

Manfaat dalam penelitian ini adalah memperkaya ilmu pengetahuan atau wawasan khususnya tentang strategi coping santri dalam menghadapi standar kelulusan ditinjau dari Psikologi Pendidikan. Kemudian memberikan manfaat bagi informan agar mulai berfokus untuk mengembangkan strategi coping dalam menghadapi standar kelulusan sehingga santri mampu mampu memenuhi profil kelulusan yang sesuai dengan harapan pondok pesantren dan memberikan wawasan bagi pihak sekolah mengenai strategi coping santri dalam menghadapi standar kelulusan sehingga pihak sekolah dapat memberikan fasilitas yang mendukung santri dalam menghadapi tekanan tersebut.

Penelitian ini dilakukan atas dasar beberapa peneliti sebelumnya yang mengkaji tentang Coping strategies of high school students with learning disabilities: a longitudinal qualitative study and grounded theory oleh Givon dan Court (2009). Hasil pada penelitian ini menemukan 
bahwa intervensi dari diagnosis dini dan keakuratan dalam memahami kesulitan yang dialami anak, disertai dengan pengajaran yang dilakukan secara berulang dan dukungan sosial merupakan hal penting dalam mengembangankan strategi coping pada siswa. Letak perbedaan penelitian saya dengan penelitian sebelumnya yaitu, peneliti lebih mengkaji pada strategi coping dalam menghadapi standar kelulusan. Kemudian untuk subjek penelitian, peneliti memilih santri pondok pesantren yang memiliki latar belakang berbeda dengan siswa pada sekolah umum yang mendapat pendampingan dari orang tua dan keluarga, dimana santri harus tinggal berjauhan dengan orang tua dan keluarga sehingga hasil dari penelitian ini dapat menambah khasanah penelitian yang sebelumnya mengenai strategi coping pada siswa menengah atas.

Kemudian terdapat pula penelitian Sulaeman (2014), yang mengkaji tentang Studi Deskriptif Mengenai Derajat Stres dan Strategi Coping Stress Siswa Tsanawiyyah Al-Furqon Islamic Boarding School. Hasil dari penelitian ini mengungkapkan bahwa tuntutan akademik, relasi sosial, dan peraturan yang ada di Al-Furqon Islamic Boarding School membuat para siswa stres. Strategi coping stress yang digunakan oleh para siswa menyebar pada semua bentukbentuk strategi coping. Namun, strategi yang paling dominan digunakan oleh para siswa Tsanawiyyah adalah distancing dan seeking social support merupakan sudimensi strategi emotion-focused coping. Letak perbedaan penelitian ini dengan penelitian saya adalah pemilihan subjek, yaitu penelitian sebelumnya memilih santri Tsanawiyah (setaraf siswa di sekolah menengah pertama), sedangkan peneliti memilih santri Aliyah (setaraf siswa di sekolah menegah atas). Perbedaan usia antara santri Tsanawiyah dan Aliyah diasumsikan memiliki cara berfikir dan tingkat kedewasaan yang berbeda sehingga berpengaruh pada strategi coping yang dipilih oleh santri tersebut.

\section{B. Tinjauan Pustaka}

\section{Strategi Copig}

Strategi coping diartikan sebagai respon yang bersifat perilaku psikologis untuk mengurangi atau menghindari tekanan beserta dampaknya, sifat dinamis dan meminimalkan reaksi emosional (Compas, Connor-Smith, Saltzman, Thomsen dan Wadsworth, 2001; Pramadi dan Lasmono, 2003; Mundia, 2010). Strategi coping tidak hanya meminimalkan keadaan tertekan tetapi juga berusaha untuk memecahkan masalah yang membuat tertekan. Strategi 
coping mengacu pada cara-cara untuk menangani stres dan kesulitan dalam beberapa keadaan. strategi coping adalah usaha yang dilakukan oleh individu baik dari segi kognitif maupun perilaku untuk memecahkan, mengurangi dan menggantikan kondisi tekanan yang dinilai membebani individu. Faktor-faktor yang mempengaruhi strategi coping adalah faktor internal dan faktor eksternal. Faktor internal meliputi kepribadian dan persepsi diri. Kemudian faktor eksternal meliputi jenis masalah, dukungan keluarga, sekolah dan sosial. Strategi coping sendiri dapat dibagi menjadi dua bentuk, yaitu problem-focused coping dan emotion-focused coping.

\section{Santri dan Pondok Pesantren}

Menurut Qomar (2005), santri merupakan peserta didik. Pengertian santri lebih diperjelas lagi oleh Diponegoro (2005) bahwa santri adalah siswa yang biasanya hidup mondok di asramaasrama yang berada di lingkungan pondok pesantren. Dari pendapat-pendapat yang telah dijabarkan, maka dapat ditarik kesimpulan bahwa santri adalah siswa yang menuntut ilmu di lingkungan pondok pesantren.

\section{Strategi Coping Santri Dalam Menghadapi Standar Kelulusan di Pondok Pesantren}

Pondok Pesantren memiliki kriteria standar kelulusan bagi para santri dengan harapan agar lulusan pondok pesantren mampu mengaplikasikan pendidikan yang berorientasi ilmu syar'i (ulumuddin) dan ilmu pengetahuan umum yang diharapkan mampu menjawab tuntutan zaman dan beradaptasi dengan perkembangan masyarakat. Terdapat dua tipe utama dari bentuk strategi coping. Beberapa penelitian menemukan bahwa strategi coping yang paling sering digunakan oleh siswa menengah atas atau remaja akhir dalam menghadapi tekanan akademik yaitu problem-focused coping. Sebagaimana penelitian Nahareko (2009) yang menemukan bahwa remaja akhir adalah masa konsolidasi menuju periode dewasa dimana remaja akhir semakin mantap terhadap fungsi-fungsi inteleknya, dan dalam tahap ini terjadi perubahan kecenderungan memikirkan diri sendiri kepada kecenderungan memperhatikan orang lain, sehingga remaja akhir melakukan proses Problem Focused Coping.

Hal ini tak jauh berbeda dengan penelitian Suwarti (2009) yang menemukan bahwa seseorang cenderung menggunakan Problem Focused Coping dalam menghadapi masalahmasalah yang menurutnya bisa dikontrol seperti masalah yang berhubungan dengan sekolah atau pekerjaan. Sehingga dapat disimpulkan bahwa remaja akhir yang mengalami tekanan dalam menghadapi tugas dan standar kelulusan di sekolah, cenderung melakukan Problem Focused 
Coping untuk mengatasi kondisi tertekan tersebut. Melihat latar belakang santri yang tinggal berjauhan dengan orang tua dan keluarga, problem-focused coping juga melupakan strategi coping yang paling sering digunakan meliputi pemecahan masalah, bekerja keras, fokus pada positif dan dukungan sosial (Shahrill dan Mundia, 2014).

\section{Pertanyaan Penelitian}

Berdasarkan beberapa uraian di atas maka muncul pertanyaan dalam penelitian ini, yaitu:

1. Bagaimana persepsi santri terhadap standar kelulusan yang ditetapkan oleh pondok pesantren?

2. Bagaimana bentuk-bentuk strategi coping santri dalam menghadapi standar kelulusan di pondok pesantren?

3. Apa saja faktor-faktor yang mempengaruhi strategi coping santri dalam menghadapi standar kelulusan di pondok pesantren?

\section{Metode}

Penelitian ini menggunakan metode kualitatif fenomenologi. Penelitian ini lebih berfokus pada konsep fenomena strategi coping santri dalam menghadapi standar kelulusan di pondok pesantren dan bentuk dari studinya adalah untuk melihat dan memahami arti dari suatu pengalaman santri yang berkaitan dengan persepsi santri terhadap standar kelulusan, bentukbentuk strategi coping santri dan faktor-faktor yang mempengaruhi strategi coping santri dalam menghadapi standar kelulusan di pondok pesantren.

\section{Hasil dan Pembahasan}

\section{Persepsi santri terhadap standar kelulusan yang ditetapkan oleh pondok pesantren}

Berdasarkan hasil penelitian dari 6 informan di atas, maka dapat terlihat bahwa persepsi santri terhadap standar kelulusan yang ditetapkan oleh pondok pesantren dibagi menjadi dua pendapat yaitu: 
Tabel 6. Persepsi Santri Terhadap Standar Kelulusan yang Ditetapkan oleh Pondok Pesantren

\begin{tabular}{|c|l|l|l|}
\hline \multirow{2}{*}{ No. } & Subjek & \multicolumn{2}{|c|}{ Kategori Standar Kelulusan } \\
\cline { 3 - 4 } & $\begin{array}{l}\text { Syarat Kelulusan Pondok } \\
\text { (Syarat Wisuda/Syarat } \\
\text { Pengambilan Ijazah }\end{array}$ & $\begin{array}{l}\text { Syarat Kelulusan Negara (Ujian } \\
\text { Nasional) }\end{array}$ \\
\hline 1. & Subjek 1 & Setuju & Tidak Setuju \\
\hline 2. & Subjek 2 & Setuju & Setuju \\
\hline 3. & Subjek 3 & Setuju & Setuju \\
\hline 4. & Subjek 4 & Setuju & Tidak Setuju \\
\hline 5. & Subjek 5 & Setuju & Tidak Setuju \\
\hline 6. & Subjek 6 & Setuju & Setuju \\
\hline
\end{tabular}

a. Setuju dengan syarat kelulusan pondok (syarat wisuda/syarat pengambilan ijazah) (Subjek 1, 2, 3, 4, 5 dan 6) dan syarat kelulusan negara (Ujian Nasional) (Subjek 2, 3 dan 6), dengan alasan:

1) Syarat kelulusan pondok sebagai sarana melatih santri dalam belajar menulis karya ilmiah, konsekuensi dari setiap pilihan yang telah dipilih oleh santri, menambah ilmu positif bagi masa remaja khususnya dalam hal mengatur waktu dan mengatur skala prioritas dalam hidup, sebagai sarana untuk menujukkan bahwa alumni pondok memiliki nilai lebih dibandingkan dengan alumni sekolah umum, mampu bersaing dan lebih dapat diterima di masyarakat.

2) Syarat kelulusan negara membantu nilai kelulusan, mengetes kemampuan dan pemahaman yang dimiliki oleh santri setelah lulus dari jenjang pendidikan SMA.

b. Tidak setuju (Subjek 1, 4 dan 5) dengan syarat kelulusan negara (Ujian Nasional), dengan alasan :

1) Beban berat khususnya ketika menggunakan kurikulum 2013.

2) Ketidakadilan bagi sekolah-sekolah di pelosok yang mungkin materi pelajaran yang disampaikan dan fasilitas sekolah masih kurang jika dibandingkan dengan sekolah di kota besar.

3) Tidak adil jika hasil dari belajar tiga tahun hanya ditentukan oleh beberapa mata pelajaran sedangkan masing-masing anak memiliki kecerdasan masing-masing, baik dari segi akademik maupun non akademik. Syarat kelulusan pondok yang paling membebani santri adalah: 
Tabel 7. Syarat Kelulusan Pondok yang Paling Membebani Santri

\begin{tabular}{|c|c|c|}
\hline No. & Subjek & Syarat Kelulusan Pondok \\
\hline 1. & Subjek 1 & Tahfidz (Hafalan Al-Quran) \\
\hline 2. & Subjek 2 & Tahfidz (Hafalan Al-Quran) \\
\hline 3. & Subjek 3 & Tahfidz (Hafalan Al-Quran) \\
\hline 4. & Subjek 4 & Karya Tulis \\
\hline 5. & Subjek 5 & Tahfidz (Hafalan Al-Quran) \\
\hline 6. & Subjek 6 & Tahfidz (Hafalan Al-Quran) \\
\hline
\end{tabular}

Alasan santri memilih tahfidz (hafalan Al-Quran) sebagai syarat kelulusan pondok yang paling membebani santri adalah tanggungan yang berat ketika santri melupakan ayat Al-Quran yang sudah dihafalkan, kesulitan dalam menghafal Al-Quran, waktu yang relatif singkat untuk menghafalkan Al-Quran, keinginan untuk membaca Al-Quran dengan benar dan memahami arti dari ayat yang dihafalkan. Kemudian untuk alasan santri memilih karya tulis sebagai syarat kelulusan pondok yang paling membebani santri adalah penggunaan Bahasa Asing (Bahasa Arab dan Bahasa Inggris) dalam pembuatan karya tulis dan tidak diperbolehkannya alat elektronik di dalam pondok sehingga santri mengalami kesulitan dalam mengerjakan karya tulis serta mencari referensi bahasa dan kosa kata.

Hal yang santri rasakan ketika menghadapi standar kelulusan yang ditetapkan oleh pondok pesantren dan negara adalah:

Tabel 8. Hal yang Santri Rasakan Ketika Menghadapi Standar Kelulusan yang Ditetapkan oleh Pondok Pesantren dan Negara

\begin{tabular}{|c|l|c|}
\hline No. & Subjek & $\begin{array}{c}\text { Hal yang Santri Rasakan Ketika Menghadapi } \\
\text { Standar Kelulusan }\end{array}$ \\
\hline 1. & Subjek 1 & Tertekan dan Bosan \\
\hline 2. & Subjek 2 & Tertekan \\
\hline 3. & Subjek 3 & Tertekan \\
\hline 4. & Subjek 4 & Tertekan \\
\hline 5. & Subjek 5 & Bosan dan Senang \\
\hline 6. & Subjek 6 & Tertekan \\
\hline
\end{tabular}

a. Tertekan karena bingung mengatur waktu dan skala prioritas belajar (Subjek 1, 2, 3, 4 dan 6).

Penjabaran rasa tertekan pada subjek, dijabarkan sebagai berikut:

1) Pada subjek 1, melihat standar kelulusan yang ditetapkan oleh pondok pesantren, baik dari syarat kelulusan pondok maupun syarat kelulusan negara, hal yang subjek rasakan ketika menghadapi standar kelulusan tersebut adalah tertekan karena bingung mengatur 
waktu. Meskipun begitu, subjek mencoba untuk menghadapi perasaan tertekan tersebut dengan santai. Subjek mencoba untuk menghadapi dengan santai karena subjek berfikir bahwa sudah pernah mengalami standar kelulusan sebelumnya yaitu ketika subjek berada di bangku SMP.

2) Subjek 2 merasa tertekan ketika menghadapi standar kelulusan di pondok pesantren. Namun, subjek berusaha untuk menemukan cara dalam menghadapi standar kelulusan tersebut.

3) Pada Subjek 3, seiring dengan berjalannya waktu, subjek berusaha untuk menjalani semua standar kelulusan yang ditetapkan oleh pondok pesantren. Pada awalnya subjek merasa tertekan ketika dihadapkan pada standar kelulusan pondok dan negara. Namun, subjek berusaha untuk menjalani dengan usaha, niat dan doa.

4) Pada subjek 4, melihat standar kelulusan yang ditetapkan oleh pondok pesantren, subjek merasa sedikit tertekan terutama ketika dihadapkan dengan karya tulis dan belajar untuk UN.

5) Pada subjek 6, hal yang subjek rasakan ketika menghadapi standar kelulusan adalah tertekan karena bingung mengatur waktu dan skala prioritas belajar. Bahkan subjek mengaku kesulitan dalam beristirahat sampai subjek mengalami sulit tidur.

b. Bosan karena kegiatan pondok yang padat dan kurang ada hiburan sehingga tidak update (Subjek 1 dan 5).

Penjabaran rasa bosan pada subjek dijabarkan sebagai berikut:

1) Subjek 1 merasa bosan karena kegiatan pondok yang padat, mulai dari sekolah sore sampai dengan kewajiban untuk menghafalkan Al-Quran sebagai syarat pengambilan ijazah. Meskipun begitu, subjek mencoba untuk menghadapi perasaan tertekan tersebut dengan santai.

2) Subjek 5 terkadang merasa bosan karena kurang update dengan dunia luar.

c. Senang karena dapat menyelesaikan pendidikan di pondok pesantren dan mendapatkan ilmu agama yang lebih baik (Subjek 5).

Penjabaran rasa senang pada subjek dijabarkan sebagai berikut: 
1) Perasaan yang dirasakan oleh subjek 5 dalam menghadapi syarat kelulusan pondok dan UN adalah campur aduk. Subjek merasa senang karena subjek bersyukur dapat lulus dari pondok dan lebih memahami ilmu agama dengan lebih baik.

Hasil penelitian di atas mengenai persepsi santri terhadap standar kelulusan yang ditetapkan oleh pondok pesantren sesuai dengan teori yang dikemukakan oleh Sulaeman (2014), yang menyatakan bahwa sebanyak $86 \%$ santri mengalami tekanan, yang disebabkan oleh tuntutan akademik, relasi sosial dan peraturan. Kemudian, 37\% santri mengalami tekanan yang disebabkan oleh tuntutan akademik yang berkaitan dengan standar kelulusan, berupa banyaknya mata pelajaran yang harus dikuasai, mulai dari pelajaran umum dan agama, serta tuntutan dalam menghafal Al-Quran.

\section{Bentuk-bentuk strategi coping santri dalam menghadap standar kelulusan di pondok pesantren}

Berdasarkan hasil penelitian dari 6 informan di atas, maka dapat terlihat bahwa bentuk-bentuk strategi coping santri dalam menghadapi standar kelulusan di pondok pesantren adalah emotion-focused coping dan problem-focused coping. Namun, strategi coping yang paling efektif bagi santri adalah adalah problem-focused coping. Strategi coping yang santri lakukan dalam menghadapi syarat kelulusan pondok, diantaranya adalah:

\section{Tabel 9. Strategi Coping Santri dalam Menghadapi Syarat Kelulusan Pondok}

\begin{tabular}{|c|c|}
\hline No. & Strategi Coping Santri \\
\hline 1. & Subjek 1: \\
& a. Cara subjek dalam menghadapi tekanan dari syarat kelulusan pondok (syarat \\
wisuda/syarat pengambilan ijazah), dibagi menjadi dua, yaitu dalam menghadapi \\
tekanan yang disebabkan oleh tahfidz (hafalan Al-Quran) dan tekanan yang \\
disebabkan oleh karya tulis. \\
1) Cara yang dilakukan subjek dalam menghadapi tekanan yang disebabkan \\
oleh tahfidz (hafalan Al-Quran) adalah dengan menumbuhkan kesadaran \\
diri. Subjek menghafal setiap selesai sholat maghrib dan langsung menyetor \\
hafalan kepada guru pembimbing. \\
2) Cara yang dilakukan subjek dalam menghadapi tekanan yang disebabkan \\
oleh karya tulis adalah banyak berdiskusi dengan teman dalam \\
menyelesaikan karya tulis. \\
b. Cara yang paling efektif menurut subjek adalah memilih tempat yang kondusif \\
untuk menghafal Al-Quran karena subjek mengaku sulit berkonsetrasi ketika
\end{tabular}




\begin{tabular}{|c|c|}
\hline & $\begin{array}{l}\text { dalam keadaan ramai dan menyicil dari tahun sebelumnya. Subjek merasa } \\
\text { terbantu dengan adanya pembimbingan karya tulis yang sudah dilakukan sejak } \\
\text { kelas satu sehingga subjek bisa menyelesaikan karya tulis dengan cepat. }\end{array}$ \\
\hline 2. & $\begin{array}{l}\text { Subjek 2: } \\
\text { a. Cara subjek dalam menghadapi tekanan dari syarat kelulusan di pondok (syarat } \\
\text { wisuda/syarat pengambilan ijazah) adalah dengan belajar, berusaha sesuai } \\
\text { kemampuan dan pasrah. } \\
\text { b. Jika melihat dari jenis syarat kelulusan pondok, maka cara subjek dalam } \\
\text { menghadapi tekanan dapat dispesifikasikan menjadi dua, yaitu: } \\
\text { 1) Cara subjek dalam menghadapi syarat tahfidz (hafalan Al-Quran) adalah } \\
\text { dengan membaca setiap hari dan menghafalkan satu-dua ayat kemudian } \\
\text { langsung disetorkan kepada ustadzah. } \\
\text { 2) Cara subjek dalam menghadapi syarat karya tulis adalah dengan cara } \\
\text { mengejar target. Subjek mencari di internet. Subjek juga merasa bahwa } \\
\text { karya tulis lebih mudah daripada tahfidz. } \\
\text { c. Cara yang paling efektif dalam menghadapi tekanan yang disebabkan oleh syarat } \\
\text { kelulusan pondok menurut subjek adalah sering membaca dan langsung } \\
\text { menyetor hafalan kepada guru pembimbing. }\end{array}$ \\
\hline 3. & $\begin{array}{l}\text { Subjek 3: } \\
\text { a. Cara subjek dalam menghadapi tekanan dari syarat kelulusan pondok (syarat } \\
\text { wisuda/syarat pengambilan ijazah) adalah berusaha untuk menghadapi semua } \\
\text { tantangan syarat kelulusan pondok dan istiqomah (konsisten) dalam menjalankan } \\
\text { semua syarat tersebut. } \\
\text { b. Jika melihat dari jenis syarat kelulusan pondok, maka cara subjek dalam } \\
\text { menghadapi tekanan dapat dispesifikasikan menjadi dua, yaitu: } \\
\text { 1) Cara subjek dalam menghadapi syarat tahfidz (hafalan Al-Quran) adalah } \\
\text { dengan menggunakan waktu luang sebaik-baiknya untuk menghafal. Selain } \\
\text { dengan menggunakan waktu luang dengan sebaik-baiknya, cara subjek dalam } \\
\text { menghafalkan Al-Quran adalah dengan menggunakan sya'ir. } \\
\text { 2) Cara sujek dalam menyelesaikan karya tulis adalah dengan memanfaatkan } \\
\text { waktu kosong untuk mengerjakan karya tulis. } \\
\text { c. Cara yang paling efektif dalam menghadapi syarat kelulusan pondok menurut } \\
\text { subjek adalah dengan istiqomah (konsisten), niat, usaha dan berdoa. }\end{array}$ \\
\hline 4. & $\begin{array}{l}\text { Subjek 4: } \\
\text { a. Cara subjek dalam menghadapi tekanan dari syarat kelulusan pondok (syarat } \\
\text { wisuda/syarat pengambilan ijazah) adalah mengatur waktu dengan baik } \\
\text { (pembagian waktu untuk menyelesaikan syarat kelulusan dan pemanfaatan waktu } \\
\text { luang. } \\
\text { b. Cara yang paling efektif menurut subjek adalah memilih tempat yang kondusif } \\
\text { untuk menghafal Al-Quran dan sering mengulang-ulang hafalan, dan rutin } \\
\text { berkonsultasi dengan pembimbing. }\end{array}$ \\
\hline
\end{tabular}




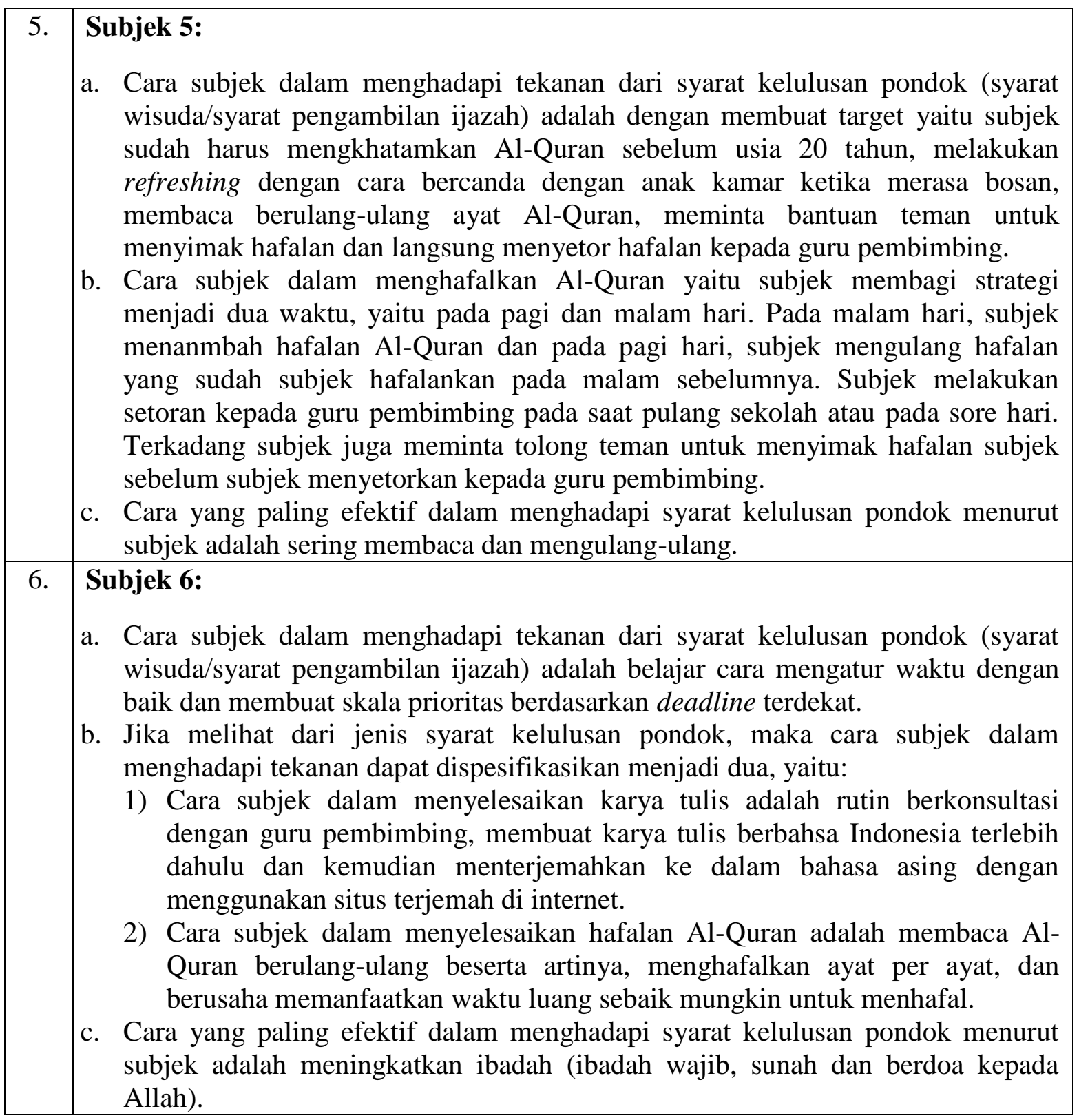

Kemudian strategi coping yang santri lakukan dalam menghadapi syarat kelulusan negara, diantaranya adalah:

Tabel 10. Strategi Coping Santri dalam Menghadapi Syarat Kelulusan Negara

\begin{tabular}{|c|l|}
\hline No. & \multicolumn{1}{|c|}{ Strategi Coping Santri } \\
\hline 1. & Subjek 1: \\
& $\begin{array}{l}\text { a. Cara subjek dalam menghadapi tekanan dari UN adalah belajar dan mujahadah. } \\
\text { b. } \quad \text { Menurut subjek, ketika syarat kelulusan dibuat pusing, maka akan semakin terasa }\end{array}$ \\
\hline
\end{tabular}




\begin{tabular}{|c|c|}
\hline & $\begin{array}{l}\text { pusing. Oleh sebab itu, subjek berusaha untuk menghadapi tekanan yang } \\
\text { disebabkan oleh standar kelulusan dengan santai. } \\
\text { c. Cara yang paling efektif menurut subjek dalam menghadapi tekanan dari UN } \\
\text { adalah adalah istiqomah (konsisten) dalam belajar dan berdoa. }\end{array}$ \\
\hline 2. & $\begin{array}{l}\text { Subjek 2: } \\
\text { a. Cara subjek dalam menghadapi tekanan dari UN adalah belajar, refreshing, } \\
\text { mengikuti bimbel dan berdoa. Refreshing yang dilakukan subjek adalah dengan } \\
\text { izin keluar komplek. Subjek juga mengaku bahwa subjek berhubungan dengan } \\
\text { lawan jenis agar mendapatkan motivasi dan semangat dari orang yang spesial. } \\
\text { b. Cara yang paling efektif menurut subjek adalah mengikuti bimbingan belajar dan } \\
\text { meningkatkan ibadah kepada Allah (berdoa dan ibadah sunah). }\end{array}$ \\
\hline 3. & $\begin{array}{l}\text { Subjek 3: } \\
\text { a. Cara subjek dalam menghadapi tekanan dari UN adalah dengan berikhtiar, } \\
\text { bertawakal dan menebalkan iman. Menebalkan iman dilakukan dengan } \\
\text { menjalankan puasa sunah dan sholat berjamaah. Cara lain dalam menghadapi } \\
\text { tekanan yang disebabkan karena UN adalah dengan mengikuti bimbel. } \\
\text { b. Cara yang paling efektif dalam menghadapi UN menurut subjek adalah belajar } \\
\text { bersama dengan teman. Subjek merasa bahwa di pondok pesantren, hubungan } \\
\text { antara putra dan putri masih terasa sungkan. Namun, sejak kelas XII, pembatas } \\
\text { berupa sartir di kelas antara putra dan putrid sudah tidak dipergunakan agar } \\
\text { kerjasama dalam belajar antara putra dan putrid dapat terjalin dengan baik. }\end{array}$ \\
\hline 4. & $\begin{array}{l}\text { Subjek 4: } \\
\text { a. Cara subjek dalam menghadapi tekanan dari UN adalah memperbanyak latihan } \\
\text { soal dan megikuti les. Bahkan subjek bercerita bahwa subjek berusaha untuk } \\
\text { tidak tidur siang. Subjek khawatir apabila subjek tidur siang, maka subjek akan } \\
\text { sulit tidur pada malam hari dan harus bergadang. Oleh sebab itu, pada waktu } \\
\text { siang hari, subjek mengisi waktu dengan belajar memperbanyak latihan soal. } \\
\text { b. Cara yang paling efektif menurut subjek dalam menghadapi UN adalah } \\
\text { memperbanyak latihan soal-soal. }\end{array}$ \\
\hline 5. & $\begin{array}{l}\text { Subjek 5: } \\
\text { a. Cara subjek dalam menghadapi tekanan dari UN adalah dengan belajar. Namun } \\
\text { di samping itu, subjek juga meningkatkan hafalan Al-Quran karena subjek } \\
\text { meyakini bahwa mengaji dan menghafalkan Al-Quran dapat memberikan syafaat } \\
\text { kepada subjek sehingga subjek dapat menghadapi UN dengan baik. } \\
\text { b. Cara yang paling efektif menurut subjek dalam menghadapi UN adalah } \\
\text { meningkatkan ibadah kepada Allah dengan cara menghafalkan Al-Quran dan } \\
\text { berdoa. }\end{array}$ \\
\hline 6. & $\begin{array}{l}\text { anan dari UN adalah mengikuti pengayaan, } \\
\text { g soal dan mempelajari materi dimulai dari } \\
\text { ahulu. }\end{array}$ \\
\hline
\end{tabular}




\begin{tabular}{|l|l|}
\hline b. Cara yang paling efektif menurut subjek adalah mengerjakan sendiri terlebih \\
dahulu, berdiskusi dengan teman dan mengulang-ulang materi. \\
c. Subjek mengaku bahwa dalam menghadapi standar kelulusan di pondok \\
pesantren, terkadang subjek merasa bosan. Namun subjek berusaha menghadapi \\
kebosanan tersebut dengan cara membaca buku cerita, menghibur diri dengan \\
cara bernyanyi dan mencuci baju.
\end{tabular}

Hasil penelitian di atas mengenai bentuk-bentuk strategi coping santri dalam menghadapi standar kelulusan di pondok pesantren sesuai dengan teori yang dikemukakan oleh Nahareko (2009) yang menemukan bahwa remaja akhir adalah masa konsolidasi menuju periode dewasa. Pada masa ini, remaja akhir semakin mantap terhadap fungsi-fungsi inteleknya, dan dalam tahap ini terjadi perubahan kecenderungan memikirkan diri sendiri kepada kecenderungan memperhatikan orang lain, sehingga remaja akhir melakukan proses Problem Focused Coping. Kemudian melihat latar belakang santri yang tinggal berjauhan dengan orang tua dan keluarga, Problem-Focused Coping juga melupakan strategi coping yang paling sering digunakan meliputi pemecahan masalah, bekerja keras, fokus pada positif dan dukungan sosial (Shahrill dan Mundia, 2014).

3. Faktor-faktor yang mempengaruhi strategi coping santri dalam menghadapi standar kelulusan di pondok pesantren

Berdasarkan hasil penelitian dari 6 informan di atas, maka dapat terlihat bahwa faktor-faktor yang mempengaruhi strategi coping santri dalam menghadapi standar kelulusan di pondok pesantren berasal dari faktor internal dan faktor eksternal. Faktor internal meliputi karakteristik personal (kepribadian dan cara santri dalam menyelesaikan masalah) dan persepsi diri (cara santri dalam menilai diri santri sendiri). Pengaruh faktor internal terlihat pada keenam orang subjek dalam menyelesaikan masalah dan dalam menilai diri sendiri, seperti:

Tabel 11. Pengaruh Faktor Internal Terhadap Strategi Coping Santri

\begin{tabular}{|l|l|}
\hline No. & Faktor Internal (Karakteristik Personal dan Persepsi Diri) \\
\hline 1. & Subjek 1: \\
& a. Cara subjek dalam menyelesaikan masalah adalah langsung menghadapi dan \\
& $\begin{array}{l}\text { menyelesaikan masalah tersebut. Subjek berpendapat bahwa ketika masalah } \\
\text { ditunda-tunda, maka akan semakin menumpuk dan merepotkan. }\end{array}$ \\
& $\begin{array}{l}\text { b. Penilaian subjek terhadap diri sendiri adalah cenderung tergesa-gesa dan ingin } \\
\text { masalah cepat terselesaikan. Selain itu, subjek juga merasa bahwa subjek masih } \\
\text { suka berfikir pendek. }\end{array}$ \\
\hline
\end{tabular}




\begin{tabular}{|c|c|}
\hline 2. & $\begin{array}{l}\text { Subjek 2: } \\
\text { a. Cara subjek dalam menyelesaikan masalah adalah berusaha berfikir dengan dewasa } \\
\text { dan memohon kepada Allah agar menjernihkan pikiran subjek. } \\
\text { b. Meskipun terkadang subjek menilai diri subjek sendiri masih kurang mampu dalam } \\
\text { mengontrol emosi. Subjek merasa terkadang masih seperti anak kecil, sehingga } \\
\text { dalam menyelesaikan masalah masih dengan emosi yang tidak terkontrol, seperti } \\
\text { marah-marah. }\end{array}$ \\
\hline 3. & $\begin{array}{l}\text { Subjek 3: } \\
\text { a. Cara subjek dalam menyelesaikan masalah adalah langsung menyelesaikan masalah } \\
\text { tersebut dengan cepat, tenang, kepala dingin dan tidak menghindari masalah. } \\
\text { b. Penilaian subjek terhadap diri sendiri adalah subjek merupakan orang yang } \\
\text { melakukan segala sesuatu sesuai dengan kemampuan subjek. Subjek berusaha untuk } \\
\text { merencanakan segala hal dengan baik sebelum melakukan sesuatu. }\end{array}$ \\
\hline 4. & $\begin{array}{l}\text { Subjek 4: } \\
\text { a. Cara subjek dalam menyelesaikan masalah adalah menganalisis masalah terlebih } \\
\text { dahulu dengan mempertimbangkan pandangan ke depan terhadap keputusan yang } \\
\text { akan diambil. } \\
\text { b. Subjek menilai diri sendiri sebagai individu yang mampu menyelesaikan masalh } \\
\text { sendiri. Bahkan subjek merupakan tempat curahan hati bagi teman-teman yang } \\
\text { sedang memiliki masalah. Subjek merupakan orang yang selalu berorientasi ke } \\
\text { depan. }\end{array}$ \\
\hline 5. & $\begin{array}{l}\text { Subjek 5: } \\
\text { a. Cara subjek dalam menyelesaikan masalah adalah langsung menghadapi masalah } \\
\text { itu sendiri. Namun jika masalah tersebut dirasa sulit, maka subjek akan menghindari } \\
\text { masalah tersebut terlebih dahulu kemudan datang kembali untuk menyelesaikan. } \\
\text { Selain itu, ketika ada masalah maka subjek akan berdiskusi dengan teman dekat, } \\
\text { beribadah dan berdoa kepada Allah serta tidak memikirkan masalah yang sekiranya } \\
\text { tidak penting. } \\
\text { b. Penilaian subjek terhadap diri sendiri adalah perfeksionis (ingin sempurna dan } \\
\text { maksimal dalam mengerjakan segala sesuatu). }\end{array}$ \\
\hline 6 & $\begin{array}{l}\text { Subjek 6: } \\
\text { a. Cara subjek dalam menyelesaikan masalah adalah berusaha tidak menghindar, } \\
\text { menghadapi dengan dewasa, bercerita dengan teman dan berdiskusi mencari solusi } \\
\text { bersama. } \\
\text { b. Meskipun begitu, subjek menilai diri sendiri sebagai orang yang masih } \\
\text { membutuhkan orang lain untuk membantu menyelesaikan masalah dan memberikan } \\
\text { solusi, yaitu orang tua dan teman. Subjek juga merasa bahwa subjek merupakan } \\
\text { orang yang tidak suka menunda-nuad masalah dan berusaha menyelesaikan masalah } \\
\text { tersbeut secepat mungkin. }\end{array}$ \\
\hline
\end{tabular}


Kemudian untuk faktor eksternal, meliputi dukungan keluarga, sekolah dan sosial. Dukungan keluarga kepada santri untuk menghadapi tekanan yang disebabkan oleh standar kelulusan diantaranya adalah:

a. Menelfon dan menjenguk (Subjek 1,2 dan 4)

b. Mencari nafkah untuk anak, menambah uang saku dan memenuhi kebutuhan anak dalam menghadapi standar kelulusan (Subjek 3, 5 dan 6)

c. Mengajak berbincang, memberi motivasi, dukungan, semangat, masukan dan arahan tanpa memaksakan kehendak anak (Subjek 1, 2 dan 4)

d. Mendoakan, meridhoi, dan berpuasa ketika anak sedang melangsungkan tes (Subjek 1, 5 dan 6).

Dukungan sekolah kepada santri untuk menghadapi tekanan yang disebabkan oleh standar kelulusan diantaranya adalah:

a. Memberi semangat, motivasi dan informasi terbaru (Subjek 2, dan 4)

b. Memberikan tutor atau guru baik dari dalam sekolah maupun dari luar, mengadakan bimbingan belajar, les tambahan, pemadatan jadwal, memberikan fasilitas kepada santri berupa menyediakan laptop untuk mengerjakan karya tulis, mempermudah jadwal berkonsultasi dengan santri dan mengadakan camp tahfidz (Subjek 1, 2, 3, 4, 5 dan 6)

c. Mengadakan mujahadah (doa khusus secara bersama), mengadakan ziarah kubur kyai dan tahlilan (Subjek 1, 3 dan 5).

Dukungan sosial dalam hal ini adalah teman karena di dalam pondok pesantren teman merupakan dukungan sosial yang paling dekat. Dukungan teman kepada santri untuk menghadapi tekanan yang disebabkan oleh standar kelulusan adalah dengan:

a. Saling membantu, mengingatkan, menasehati, menyemangati, saling bertukar pikiran untuk mencari solusi bersama (Subjek 2, 4 dan 6).

b. Belajar bersama, saling berbaur satu dengan yang lain dan menjaga kekompakan (Subjek 1 dan 3).

Hasil penelitian di atas mengenai faktor-faktor yang mempengaruhi strategi coping santri dalam menghadapi standar kelulusan di pondok pesantren sesuai dengan teori yang dikemukakan oleh Givon dan Court (2009) bahwa faktor-faktor yang mempengaruhi strategi coping dapat dibagi menjadi dua, yaitu faktor kondisi ekternal dan faktor kondisi internal. Faktor kondisi 
eksternal seperti dukungan keluarga, dukungan sosial dan dukungan sekolah dan faktor kondisi internal seperti karakteristik personal, persepsi diri, tahap dimana siswa berada di dalam proses penerimaan kekurangan dan persepsi kekurangan sebagai bagian dari identitas konsolidasi pada remaja.

Setelah melakukan penelitian, analisis dan pembahasan, maka peneliti dapat memberikan keterbatasan dalam penelitian ini, diantaranya adalah peneliti hanya melakukan wawancara satudua kali kepada subjek dan dilakukan dalam waktu 30-50 menit. Hal tersebut menyebabkan data yang diperoleh tidak kaya dan kurang eksploratif. Hal tersebut dapat disebabkan karena peneliti yang kurang mampu dalam mengeksplorasi dalam melakukan wawancara sehingga informan kurang memahami pertanyaan peeliti. Dapat pula disebabkan karena informan peneliti merupakan pribadi yang pemalu atau butuh waktu yang lebih lama untuk dapat merasa nyaman dengan orang baru sehingga terlalu singkat dalam menjawab pertanyaan peneliti.

\section{E. Kesimpulan dan Saran}

Berdasarkan hasil analisis dan pembahasan penelitian maka dapat disimpulkan mengenai strategi coping santri dalam menghadapi standar kelulusan di pondok pesantren adalah sebagai berikut:

1. Persepsi santri terhadap standar kelulusan yang ditetapkan oleh pondok pesantren dibagi menjadi dua pendapat, yaitu: a) Setuju dengan syarat kelulusan pondok (syarat wisuda/syarat pengambilan ijazah) dan syarat kelulusan negara (Ujian Nasional), dengan alasan syarat kelulusan pondok sebagai sarana melatih santri dalam belajar menulis karya ilmiah, konsekuensi dari setiap pilihan yang telah dipilih oleh santri, menambah ilmu positif bagi masa remaja dalam hal mengatur waktu dan mengatur skala prioritas dalam hidup, sarana untuk menujukkan bahwa alumni pondok memiliki nilai lebih dibandingkan dengan alumni sekolah umum, mampu bersaing dan lebih dapat diterima di masyarakat. Syarat kelulusan negara membantu nilai kelulusan, mengetes kemampuan dan pemahaman yang dimiliki oleh santri setelah lulus SMA; dan b) Tidak setuju dengan syarat kelulusan negara (Ujian Nasional), dengan alasan beban berat khususnya ketika menggunakan kurikulum 2013, ketidakadilan bagi sekolah-sekolah di pelosok yang mungkin materi pelajaran dan fasilitas sekolah masih kurang jika dibandingkan dengan sekolah di kota besar dan tidak adil jika 
hasil dari belajar tiga tahun hanya ditentukan oleh beberapa mata pelajaran sedangkan masing-masing anak memiliki kecerdasan masing-masing, baik dari segi akademik maupun non akademik.

2. Bentuk strategi coping santri dalam menghadap standar kelulusan di pondok pesantren adalah emotion-focused coping dan problem-focused coping. Emotion-focused coping bertujuan untuk mengurangi atau mengelola tekanan emosional yang dikaitkan dengan situasi, misalnya, strategi seperti pengabaian dan selingan atau rekreasi. Emotion-focused coping yang dilakukan oleh santri meliputi izin keluar komplek, berhubungan dengan lawan jenis, membuka online-shop, bercanda dengan teman satu kamar, membaca buku cerita, menghibur diri dengan bernyanyi dan mencuci baju. Kemudian problem-focused coping bertujuan untuk memecahkan masalah, atau melakukan sesuatu untuk mengubah sumber stres, misalnya, strategi seperti mengontrol situasional, instruksi diri positif dan mencari dukungan. Dari dua bentuk strategi coping di atas, menurut santri problem-focused coping merupakan strategi coping yang paling efektif dalam menghadapi standar kelulusan di pondok pesantren. Problem-focused coping yang santri lakukan meliputi memilih tempat yang kondusif untuk menghafal Al-Quran dan mengerjakan karya tulis, menyicil dari tahun sebelumnya, sering membaca dan mengulang-ulang, rutin berkonsultasi dengan pembimbing, mengimbangi belajar (mengikuti bimbingan belajar, memperbanyak latihan soal-soal, bekerja dan belajar bersama dengan teman), meningkatkan ibadah (rutin menjalankan ibadah wajib, sunah dan berdoa kepada Allah) dan istiqomah (konsisten) dalam menjalankan aktivitas tersebut, baik dari segi akademik maupun religiusitas.

3. Faktor-faktor yang mempengaruhi strategi coping santri dalam menghadapi standar kelulusan di pondok pesantren dapat dibagi menjadi dua, yaitu faktor kondisi internal dan faktor eksternal. Faktor internal meliputi karakteristik personal (kepribadian dan cara santri dalam menyelesaikan masalah) dan persepsi diri (cara santri dalam menilai diri santri sendiri). Meskipun terkadang ditemukan santri yang masih belum dewasa dalam menghadapi kondisi-kondisi tertentu, seperti cenderung tergesa-gesa dan ingin masalah cepat terselesaikan, kurang mampu mengontrol emosi dan masih membutuhkan orang lain dalam menyelesaikan masalah. Namun santri berusaha untuk belajar dewasa dengan cara menyelesaikan masalah dengan langsung menghadapi dan menyelesaikan masalah tersebut, 
berfikir dewasa dan tenang, menganalisis masalah terlebih dahulu dengan mempertimbangkan orientasi ke depan, berdiskusi dengan teman dan berdoa kepada Allah SWT. Selain faktor internal, terdapat pula faktor eksternal seperti dukungan keluarga, dukungan sekolah dan dukungan sosial. Dukungan sosial dalam dalam hal ini adalah teman karena di dalam pondok pesantren teman merupakan dukungan sosial yang paling dekat.

Berdasarkan hasil penelitian dan kesimpulan, maka penulis memberikan saran antara lain kepada:

1. Bagi informan penelitian (Santri pondok pesantren)

Informan penelitian diharapkan mampu menghadapi tekanan yang disebabkan oleh standar kelulusan di pondok pesantren dengan cara membuat strategi coping yang berfokus dalam memecahkan masalah dengan baik. Strategi coping yang dapat dilakukan oleh santri diantaranya adalah belajar dengan maksimal, membuat perencanaan yang baik sesuai dengan target dan skala prioritas serta meningkatkan kedisiplinan, yaitu dalam mengatur waktu. Selain itu, santri juga dapat meningkatkan sikap optimis dan berfikir positif (husnudzon), meningkatkan ibadah dan berdoa kepada Allah SWT, serta meminta doa restu kepada orang tua dan guru.

2. Bagi keluarga

Keluarga diharapkan mampu berperan serta dalam memberi support kepada santri untuk menghadapi standar kelulusan di pondok pesantren. Peran keluarga dapat ditunjukkan dengan cara menelfon, sering menjenguk, menjaga komunikasi dan mengajak anak berbincang dan berdiskusi, memberikan motivasi, dukungan, semangat, masukan dan arahan tanpa memaksakan kehendak anak dan mendoakan anak.

3. Bagi pondok pesantren

Pondok pesantren juga diharapkan mampu berperan serta dalam memberikan support kepada santri untuk menghadapi standar kelulusan di pondok pesantren. Peran pondok pesantren dapat ditunjukkan dengan cara:

a. Memberi semangat, motivasi dan informasi terbaru.

b. Memberikan tutor atau guru baik dari dalam sekolah maupun dari luar, mengadakan bimbingan belajar, les tambahan, pemadatan jadwal, memberikan fasilitas kepada santri 
berupa menyediakan laptop untuk mengerjakan karya tulis, mempermudah jadwal berkonsultasi dengan santri dan mengadakan camp tahfidz.

c. Mengadakan mujahadah (doa khusus secara bersama), mengadakan ziarah kubur kyai dan tahlilan.

4. Bagi peneliti lain

Hasil penelitian ini dapat dimanfaatkan sebagai tambahan informasi agar selanjutnya dapat meneliti strategi coping pada seluruh santri pondok pesantren, mulai dari kelas MTs sampai dengan MA, dalam menghadapi permasalahan di pondok pesantren selain permasalahan dalam menghadapi standar kelulusan.

\section{Daftar Pustaka}

Compas, B. E., Connor-Smith, J., Saltzman, H., Thomsen, A. H., \& Wadsworth, M. E. (2001). Coping with stress during childhood and adolescence: Problems, progress, and potential in theory and research. Psychological Bulletin, 127(1), 87-127. doi: 10.1037/00332909.127.1.87.

Diponegoro, A. M. (2005). Afek dan kepuasaan hidup santri. Jurnal Psikologi Islami, 1(2), 107118. doi: 10.1080/003138042000272140.

Givon, S., \& Court, D. (2009). Coping strategies of high school students with learning disabilities: a longitudinal qualitative study and grounded theory. International Journal of Qualitative Studies in Education, 23(3), 283-303. doi: 10.1080/09518390903352343.

Nahareko, A. (2009). Coping remaja akhir terhadap perilaku selingkuh ayah. Indigenous Jurnal Ilmiah Berkala Psikologi, 11(1), 20-25.

Qomar, M. (2005). Pesantren dan Transformasi Metodologi Menuju Demokrasi Institusi. Jakarta: Erlangga.

Shahrill, M., \& Mundia, L. (2014). Coping behavior of international late adolescent students in selected Australian educational institutions. Global Journal of Health Science, 6(1), 7691. doi: 10.5539/gjhs.v6n1p76.

Sulaeman, R. F. (2014). Studi Deskriptif Mengenai Derajat Stres dan Strategi Coping Stress Siswa Tsanawiyyah Al-Furqon Islamic Boarding School. (Skripsi tidak dipublikasikan). Fakultas Psikologi Universitas Padjajaran, Bandung.

Suwarti. (2009). Strategi coping waria dalam menghadapi kecemasan terjangkit hiv/aids di Purwokerto. PSYCHO IDEA, 7(1), 35-47. 